\title{
Imprisonment during COVID-19 in Brazil: A Brief Review on the Prison Situation during the Pandemic
}

\section{Maduro FM ${ }^{1 *}$ and Fonseca $\mathrm{PM}^{2}$}

${ }^{1}$ Lawyer, Post-Doctorate degree in Human Rights and Democracy, University of Coimbra, Portugal

${ }^{2}$ Lawyer, Catholic University of Petropolis, Brazil

*Corresponding author: Flávio Mirza Maduro, Attorney at Law, Professor at Rio de Janeiro State University (UERJ); Post-Doctorate Degree in Human Rights and Democracy at University of Coimbra, Portugal; Doctor in Criminal Law \& Master in Criminal Law at Gama Filho University (UGF), Brazil, Email: flaviomirza@ mirzamalan.com.br

\section{Abstract}

This mini-review aims to reflect upon the conditions of penitentiaries in Brazil during times of the pandemic; it also brings to discussion the recent decision by the Supreme Court of Brazil which allowed for certain detainees to carry out their sentences under house arrest; in addition, it aims to discuss how the judges on lower courts have decided in light of the aforementioned Supreme Court ruling. By outlining the conditions of imprisonment that can be observed in the jailing system, the authors seek to critically reflect upon the role of justice in the society during times of hardship. The authors begin by tracing a historical background in a concise way, in order to elucidate how situations of illnesses and bereavement have developed during the years. After that, the authors compare judicial rulings involving the current prison status quo. To conclude, the authors seek to add to the debate joining the voices who cry out for more assertive measures in the preservation of life and health of detainees and prison workers.

Keywords: Prison; Pandemic; Covid-19; House Arrest; Supreme Court

\section{Introduction}

Under the yoke of the biggest sanitary crisis in history, Brazil sees itself amidst many debates that become known as soon as new problems do. One of the most prominent of these is that of imprisonment during the pandemic caused by the virus SARS-CoV-19, commonly known as the new coronavirus, which had its beginning over a year ago. It is important to stress that, in the country whose jail population consists of over 700,000 people, according to data from 2020 (National Penitentiary Department of Brazil DEPEN, 2020) [1], the number of deaths has grown significantly and reached tolls even higher than those experienced at the start of the pandemic (Unified Health System of Brazil SUS, 2021). This virus makes of the most socially vulnerable people its preferred victims [2].

These unsanitary conditions found in penitentiary establishments are widely known. It has been discussed how the imprisonment without any regard to the sanitary rules enables the spread of many diseases. At the beginning of the coronavirus pandemic, Brazilian prisons already experienced a tuberculosis outbreak, with total of cases about as thirtyfive times higher as those verified in the outside population [3]. In addition to those numbers, "four out of ten Brazilian prisons do not count on a medical facility" and exactly $48 \%$ 
of them "do not possess a pharmacy or appropriate storage room for medicine" and over " $81 \%$ do not have a washing or decontamination room" [3].

It is in this scenario that, over a year now, detainees in Brazil, whose deaths have become more and more frequent, find themselves in. However astounding as the total death toll might be, it is likely we will never know exactly how many people have succumbed to complications caused by Covid-19 [4]. In light of the wise ruling of the Supreme Court of Brazil in March 17 of last year, it is important to highlight which groups can benefit from its content. The appellate decision granted: parole to arrestees and detainees over 70years old (not in an automatic fashion, but moving up the requests of such group); house arrest to people with the HIV and other grave diseases that might be aggravated by the coronavirus, and also to nursing mothers and pregnant women, by legal determination. Moreover, the aforementioned decision recommends that, in cases where the detainee has been convicted of crimes without violence or threat of immediate force, house arrest be granted, as well as be granted substitution of provisional detention by alternate measures, extensive to those who were detained in flagrante delicto (Brazil's Supreme Court STF, 2020).

However, pursuant to caveat contained in the ruling, nobody has been released to freedom automatically. And as it has been observed in practice is this recommendation (rather, call to action) made by Supreme Court Justice Marco Aurélio has not been widely accepted by judges in courts of trial, who still remain unwavering on keeping provisional arrestees inside jail walls [5].

As it can be seen in a decision by Santa Catarina State Court [6], there has been a visible growth on the number of requests of parole and pretrial release, as well as proportional decisions denying those. It just so happens, however, that according to the Court's ruling, "house arrest is only allowed to detainees who carry out their sentences in open conditions". Even so, on the grounds of the judgerapporteur of strict appeal, "in order to be granted the benefit" it is necessary that the detainee or arrestee be eligible in one of the following conditions: "be over 70years of age, stricken by grave disease, with minor or disabled (physically or mentally) children, or pregnant situations that do not correspond to the appellee's state" (Santa Catarina State Court TJSC, 2020) [6].

The dichotomy in how this situation has been handled comes to light with a simple glance: from one side, the Supreme Court, allowing measures to contain yet another outbreak in jails throughout Brazil to be taken, and, from another, judges in trial courts presenting obstacles to the fulfillment of such decision, often times drawing support from the Law itself. It is paramount to highlight, however, that the Law, by the time of its approval, did not take into account a pandemic that threatens lives every passing day.

The situation is critical. The death toll has increased by $190 \%$ this year [7]. In addition to that, more than seven hundred thousand people live in jail cells that are "humid, unsanitary, and not isolated, remaining inside them in an average of 22 hours a day, with only two hours of sunbath". These factors, combined with "lack of a proper diet, hygiene, fresh water, and little to none access to health teams" make for "detainees' immunity to drastically decline" [8].

It is of the utmost importance to stress that Brazil's Constitution does not, by any means, allow the death penalty (or life in prison, for that matter). Nonetheless, the maintenance of a large majority of incarcerated people exactly where they are, in conditions already seen to be inhuman, is a clear transformation of the object of the sentence the deprivation of life, rather than freedom [5].

It is possible to conclude, therefore, that for a democratic State, it is highly acceptable for a detainee to return to their home, be their prison temporary or provisional, in order to carry out their sentence in house arrest. What cannot be tolerated, and one cannot stress this enough, is that lives be lost to upkeep an inherently temporary incarceration, provided that Brazil does not allow life-in-prison sentences as well $[9,10]$.

House arrest does not consist of freeing the arrestee of all their sentences, but, rather, allowing them to be carried out in a safe fashion, without exposing the arrestees to risk, as well as police force workers, or even jail workers. As Buch, trial-court judge, has cried out in Santa Catarina State Court (TJSC) [6], "are we willing to take the risk of letting people die due to the lack of courage?" Humanity, according to him, "has reached an inflection point: either we take hold of our civility, or we will be condemned by History".

\section{References}

1. (2020) National Penitentiary Department.

2. Incarceration and the Law: Case and the Materials.

3. Muniz B, Fonseca B (2020) On alert for coronavirus, prisons already facing tuberculosis epidemic. Publica.

4. Flaeschen H (2020) Coronavirus in prison: "we will probably never know the number of prisoners killed". ABRASCO.

5. Tangerino D (2020) Arrest in Covid-19 times: On the preliminary injunction at ADPF 347. 


\section{Annals of Bioethics \& Clinical Applications}

6. TJSC-Santa Catarina State Court (2020) A Covid-19 request for house arrest grows. Justice denies much of it.

7. CONJUR (2021) Deaths From Covid-19 rise $190 \%$ in Prisons Units.

8. Buch JM (2020) We Need to Talk about House Arrest in Times of Coronavirus.
9. (2020) Ruling on Arguição De Descumprimento De Preceito Fundamental. Justice-Rapporteur: Min Marco Aurélio, ADPF 347 TPI/DF. Supreme Court of Brazil.

10. Malart F, Araújo F (2020) Determined cause of death: prison.

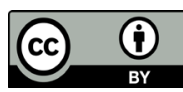

